The University of Maine

\title{
DigitalCommons@UMaine
}

Earth Science Faculty Scholarship

Earth Sciences

$7-1-2008$

\section{The Use of Ships' Protests for Reconstruction of Synoptic-Scale Weather and Tropical Storm Identification in the Late Eighteenth Century}

Louis K. McNally

Kirk A. Maasch

University of Maine - Main, kirk.maasch@maine.edu

Kimberly A. Zuill

Follow this and additional works at: https://digitalcommons.library.umaine.edu/ers_facpub

Part of the Earth Sciences Commons

\section{Repository Citation}

McNally, Louis K.; Maasch, Kirk A.; and Zuill, Kimberly A., "The Use of Ships' Protests for Reconstruction of Synoptic-Scale Weather and Tropical Storm Identification in the Late Eighteenth Century" (2008). Earth Science Faculty Scholarship. 105.

https://digitalcommons.library.umaine.edu/ers_facpub/105 


\section{The use of ships' protests for recon- struction of synoptic-scale weather and tropical storm identification in the late eighteenth century}

\section{Louis K. McNally, III, ${ }^{1}$ Kirk Allen Maasch ${ }^{2}$ and Kimberley J. Zuill ${ }^{3}$}

${ }^{1}$ Embry-Riddle Aeronautical University,
Daytona Beach, Florida, USA

2University of Maine, Orono, Maine, USA

${ }^{3}$ Bermuda Weather Service, St George's, Bermuda

Ships' protests have been used for centuries as legal documents to record and detail damages and indemnify Captains from fault. We use them in this article, along with data extracted through forensic synoptic analysis (McNally, 1994, 2004) to identify a tropical or subtropical system in the North Atlantic Ocean in 1785 . They are shown to be viable sources of meteorological information.

By comparing a damaging storm in New England in 1996, which included an offshore tropical system, with one reconstructed in 1785 , we demonstrate that the tropical system identified in a ship's protest played a significant role in the 1785 storm. With both forensic reconstruction and anecdotal evidence, we are able to assess that these storms are remarkably identical. The recurrence rate calculated in previous studies of the 1996 storm is $400-500$ years. We suggest that reconstruction of additional years in the 1700 s would provide the basis for a reanalysis of recurrence rates, with implications for future insurance and reinsurance rates. The application of the methodology to this new data source can also be used for extension of the hurricane database in the North Atlantic basin, and elsewhere, much further back into history than is currently available.

\section{Ships' protests as a data source}

In 1785 , an incident of damage sustained by an insured English ship or its cargo would be reported to the nearest Crown colony, thus protecting the Captain from insurance claims against him or the ship's owners upon arrival at his destination. Although a Notary Public deals with protests today, have to appear personally before a colonial Governor and swear out a protest. The document would then be officially recorded with the colonial Secretary.

Protests were filed for any number of reasons. Any damage to a ship or its cargo would have had grave repercussions for the Captain or the ship's owner. Without a reason for the damage, the Captain or owner could be held personally liable. In a time when a single ship's cargo could represent many personal fortunes, it was imperative that any question as to fault be removed. A Captain's reputation and career was also at risk. Thus the protest, in addition to acting as a legal deposition for the insurance syndicates, also cleared the Captain or owner of both blame and liability.

In 1785, a British ship's Captain had few options for filing a protest if an accident occurred in the western North Atlantic Ocean. Prior to that time, colonial Governors were available in many locations along the North American seaboard. The English insurance syndicates, however, would not yet recognize a document from the new United States of America, and indeed many ports and new States prohibited trade with English ships at all. Ships flagged in England were, at the time, prohibited from engaging in commerce in most American ports. In fact, they were not even allowed to call in port to swear out a protest. The nearest available port for most was Bermuda.

There are thousands of protests in the Bermuda Archives in Hamilton, Bermuda. Approximately 4800 protests exist there in various compilations and collections from the years 1693 to 1887 . For the year 1785, we found 21 protests. Of these, one deals with legal matters unrelated to maritime insurance on the Islands. Of the remainder, seven deal with non-weather-related damage events, including three mistakes in steering or navigation, two cases of improper loading, leaks, and poor crew work, and two weather events in late 1784 . The remaining 13 protests detail specific weather events, and contain valuable information for reconstructing the weather of the time. None from early 1786 refer to weather events in 1785 .

The weather observations contained in the protests are quite concise and painstakingly represented. After all, if the weather was the cause of damage to a cargo or a ship, great care would be taken to record as much as possible about the event. Indeed, the records of these weather events are revealed in far more detail than might be found in an ordinary ship's log. Thus, a reasonable reconstruction of a meteorological scenario can be achieved.

In order to extract the weather information, forensic synoptic analysis (McNally, 1994, 2004) was employed. Although translation is not necessary, the penmanship and grammar must be understood. Reverse writing, impressed upon a page from a facing page in the original ledgers, must be ignored (Figure 1). In cases where the reverse writing impression completely obscures the original, comparisons can be made with other protests. There are occasions where specific phrases and legal terminologies are repeated from document to document. Familiarity with the recording secretary's penmanship and colloquialisms can also aid in determining words or phrases which may be obscured. Because the actual weather information appears in different places in each protest, the entire document must be accurately transcribed.

As an example, Figure 2 shows a protest from the Master and Mate of the Vigilant from 1785, and is transcribed as follows:

"Bermuda alias Somers' Islands Wm Browne"

"By His Excellency William Browne Esq. Captain, General, Governor, Commander in Chief and Vice Admiral of these Islands,

To all whom this present Writing or Instrument of Protest shall come Greeting.

Know ye that this 2nd Day of February 1785 before me the Governor personally appeared Capt. Francis Hay, Master of a certain Brigantine or Vessel called the Vigilant, who solemnly made Oath on the Holy Evangelists of Almighty God, That he sailed in and with the said Brigantine from Hampton in Virginia on the 26th Day of January last past bound to St. Christophers. That on the following Day at about 4 oClock past the meridian he carried away his Foretopsail Yard, the wind blowing excessively hard from the North East by East to North West, accompanied with Thunder, Lightning, heavy Rain and Cross 


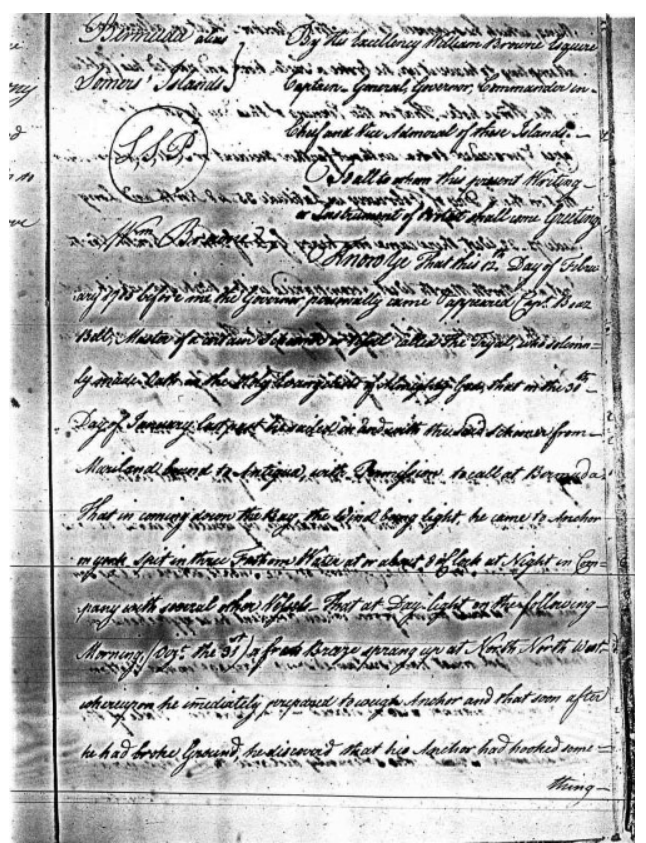

Figure 1. Example of obscuration of text by impression of reversed writing from facing page (bleedthrough). (Courtesy, Bermuda Archives.)
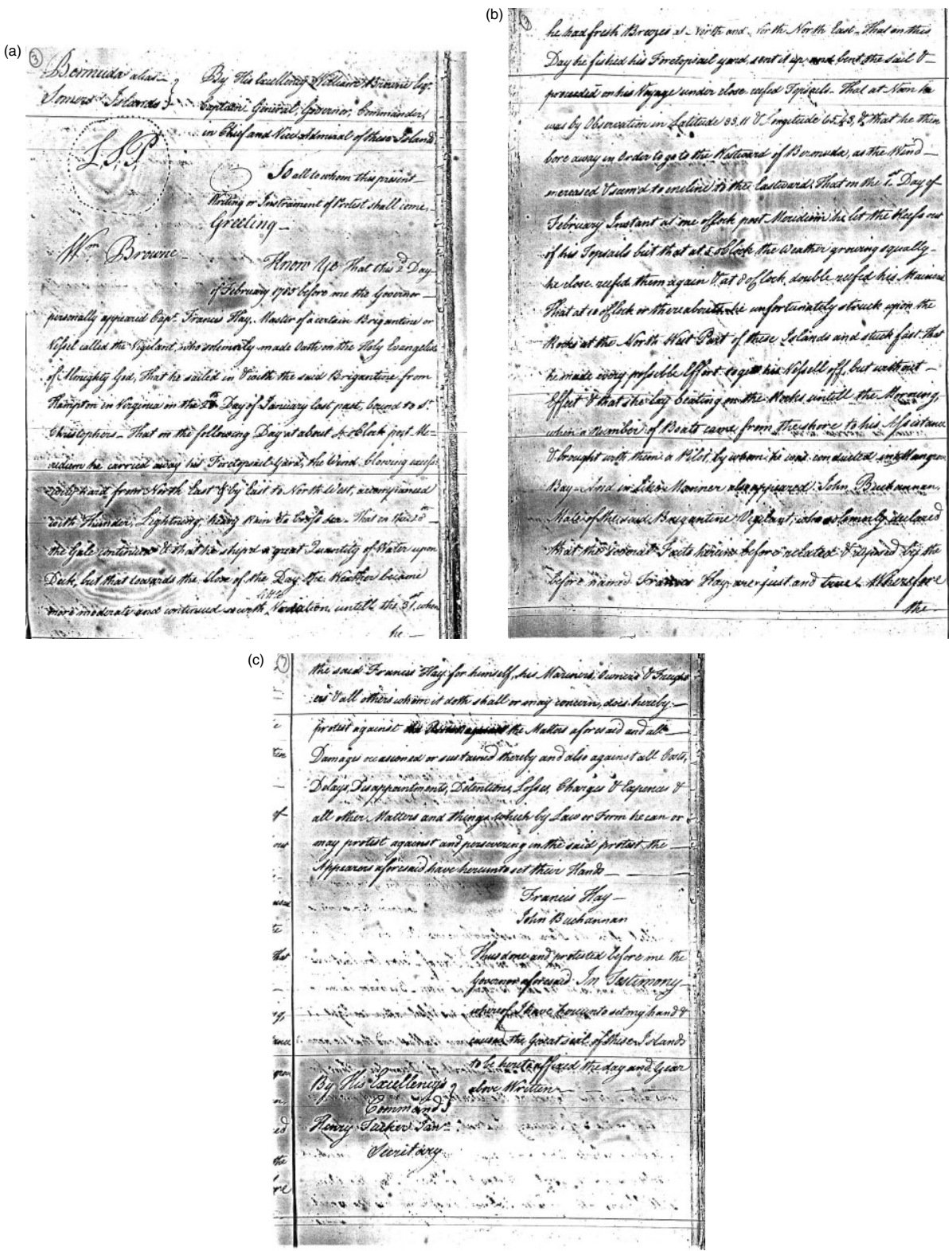

Figure 2. Ship's protest from the Vigilant, 1785. (Courtesy, Bermuda Archives.)
Sea. That on Jan 28th the Gale continued and that he shipped a great Quantity of water upon Deck, but that towards the Close of the Day the Weather became more moderate and continued with little variation until the 31 st, when he"

"he had fresh Breezes from the North and North North East. That on this Day he fished his Foretopsail yard, sent it up and bent the sail, \& proceeded on his voyage under close reefed Topsails. That at Noon he was by Observation in Latitude 33.11 \& Longitude 65.43, \& That he then bore away in Order to go to the Westward of Bermuda, as the wind increased \& seem'd to incline to the Eastward. That on the 1st Day of February Instant at one oClock past Meridian he let the Reefs out of his Topsails but that at 5 oClock the weather growing squally he close reefed them again \& at 8 oClock, double reefed his Mainsail. That at 10 oClock or thereabouts he infortunately struck upon the Rocks at the North West part of these Islands and stuck fast. That he made every possible effort to get his Vessel off, but without Effect \& that he lay beating on the Rocks until the Morning, when a number of Boats came from the shore to his Assistance \& brought with them a Pilot by whom he was conducted into Mangrove Bay. And in like Manner also appeared John Buchanan, Mate of the said Brigantine Vigilant, who solemnly declared that the several facts herein before related and defined by the before named Francis Hays were just and true. Wherefore the"

"the said Francis Hay for himself, his Mariners, Owners \& Freighters \& all others who it doth shall or may concern, does hereby protest against (overwritten) the Matters aforesaid and all Damages occasioned or sustained thereby and also against all Costs, Delays, Disappointments, Detentions, Losses, Charges \& all other Matters and things by which Law or Form he can or may protest against and persevering in the said protest the Appearers aforesaid have hereunto set their Hands.

Francis Hay

John Buchanan

This done and protested before me the Governor aforesaid In Testimony whereof I have hereunto set my hand \& caused the Great Seal of these Islands to be hereto affixed the day and Year above written By His Excellency's Command Henry Tucker Jun'r Secretary"

The importance of this protest cannot be understated, in that the Captain appeared before the Governor the very afternoon his ship was escorted into Mangrove Bay, which is at the western end of the main island in Bermuda. Whether or not the Governor was nearby is unknown, but the offices of the Governor and Secretary were at the time in St George's, at the far eastern end, $20 \mathrm{~km}$ or so away by land. 
The value of the meteorological information becomes clear in that the observations of north-east by east to north-west winds by the Master of the Vigilant, along with the notation of the thunder and lightning, indicates the passage of a frontal system strong enough to damage the ship's rigging. From the reconstruction of American observations in 1785 (McNally, 2004), there was a trailing frontal system in the Chesapeake area on 26 January, along which a storm could easily have formed, which would have moved out to sea the following day. A secondary cold front was moving offshore from New England on 27 January, which could account for the storm's intensification in the Atlantic Ocean. This would be the weather system encountered by the Vigilant on 28 January 1785.

The next storm originated as a weak low moving offshore from the Chesapeake on 29 January and intensified offshore. Its intensity is noted in America only by the lone observation of 'stormy weather' at Sandy Hook, New Jersey (Fowle's New Hampshire Gazette and General Advertiser, 1785), but was inferred by other observations of offshore winds from Virginia to Massachusetts. It is this second storm that brought the shift in the winds to the already damaged Vigilant, and eventually caused its wreck.

Additional support for these meteorological events is provided by another protest filed by the Master of the schooner Tryal. The schooner was in port in Bermuda on 31 January 1785. This account reads, in part: 'at daylight sprang up a fresh breeze at NNW', dragging the ship's anchor. However, they successfully put to sea in the evening. This could also be the same event encountered by the Vigilant on 28 January.

On 2 February, the morning after the Vigilant struck the rocks in Bermuda, and the day the Vigilant finally made port under the control of a pilot is another portion of the protest from the Tryal: 'but that on the 2nd Day of February in Latitude 35.48 North and Longitude 72.32 West there came on a heavy Gale of Wind at North North East and North North West accompanied with a high Sea which lasted with unremitting violence for forty-eight hours, during which his decks were constantly full of Water.' The Tryal eventually made it back to Bermuda only to be damaged on the shoals on approach.

Without the information from the Vigilant, it is only inference from surface winds in America and persistence from previous days' observations that indicates a storm offshore. The Sandy Hook observation, initially a candidate for 'outlier' status in a reconstruction, becomes valid when the protest from Vigilant is considered. Further verification is provided by the protest filed by the Tryal. Although both ships survived to sail another day, and the value of ships' protests as historical legal documents is certain, the additional value to forensic synoptic analysis as illustrated here in this example is apparent.

\section{Comparison of the October storms and floods of 1785 and 1996 in Southern Maine, USA}

Here we compare two nearly identical storms, one occurring in 1996, and the other more than two centuries earlier in 1785 . For the 1785 storm, similarities were recognized from both forensic reconstruction and anecdotal data. Identification of a tropical system in 1785 was accomplished through the use of a ship's protest from Bermuda, validating the comparison with the storm of 1996 in north-eastern North America. The contemporary calculated recurrence rate of the 1996 storm is $400-500$ years (Hodgkins and Stewart, 1997; Keim, 1998). Identification of the storm in 1785 , the only year reconstructed to date, suggests that further research and reconstruction may be a sound basis for reanalysis of the recurrence rate.

In the north-eastern United States, one of the most notable meteorological events in the year 1785 was the storm and flood of 18-22 October. Storm damage was reported across all of eastern New England, with concentrated flooding in the Presumpscot River Valley of southern Maine. Contemporary diary and journal entries are quite explicit regarding the intensity of the storm, its length, and its rarity in the memory of the observers. There are remarkable similarities between this storm and the notable storm and flood in the same region of New England on 18-22 October 1996, including the extent of flooding and the synoptic meteorological situation.

\section{October 1996 storm}

There are numerous sources of information regarding the October 1996 storm (Hodgkins and Stewart, 1997; Keim, 1998; Cannon, 2000) as well as the actual synoptic and cooperative observer reports from the event. There are recorded instances of excessive rainfall and flooding in southern Maine driven by either persistent banding and convergence of precipitation, or by landfalling tropical systems, such as Hurricane Bob (Sardinha, 1998). The 1996 event was uncommon, however, as it was comprised of both a mature, cut-off, extratropical, midlatitude cyclone and a direct connection via an occluded front to an offshore tropical system (Cannon, 2000). In this case, the tropical system was Hurricane Lili, which passed nearby offshore at the same time. Cannon (2000) shows the presence of an efficient advective mechanism for precipitation from Lili into an already wet extratropical system, along and north of the occluded front.

The synoptic situation for the primary storm is not uncommon. The original lowpressure system originated in Colorado, and moved eastward; it then blocked high pressure in Canada, moved to south-western Newfoundland and stalled in a slowing upper-level flow and developing block. As the surface storm matured to occlusion in Pennsylvania, having already entrained significant Gulf of Mexico moisture, the upperlevel flow became cut off, further slowing the storm's progress into northern New England. The attendant occlusion worked northward into Massachusetts, deteriorated into a trough, and lingered over the next few days. This scenario is sufficient for a sustained period of rain, occasionally heavy, but generally not sufficient for either widespread or localized flooding. Low-level convergence, however, producing a banded effect and heavier precipitation common in winter storms in the area (Malargus et al., 1995) also played a role in increasing the precipitation, and has been noted in other significant events in the area (Cannon, 1992). Some flooding might be expected from this synoptic situation.

What is not common is the entrainment and advection of the additional tropical moisture from Hurricane Lili offshore. This is the mechanism responsible for the additional excess rainfall into the specific southern Maine area. Banded tropical moisture formed a train of radar echoes and was advected towards a small area. Once this moisture was combined with that from the synoptic system, it resulted in highly localized excess precipitation. If additional bands were entrained, flooding may have become more widespread. The combined effects of both the primary storm and the tropical moisture from Hurricane Lili provide the basis for comparison with the 1785 event, which also resulted in similar flooding conditions (Figure 3).

\section{Weather in 1785}

McNally (2004) used diaries and various historical observational data to reconstruct meteorological maps on a synoptic scale for the north-eastern portion of North America for the year 1785. Previous studies (McNally, 1994) proved that successful hindcasting and accurate reconstruction of synopticscale events could be achieved with anecdotal references and very little observational data by using forensic synoptic analysis. Even small amounts of anecdotal comments alone were shown to be enough to obtain a general representation of the weather patterns at the regional synoptic scale. Apparently unrelated non-homogenous data sets, travelers' and trappers' journals, ships' logs and protests, and other sources, such as newspaper reports, were combined to reveal the workings of the atmosphere.

The general area of study encompassed north-eastern North America. Observational data used included six compilations of regular weather observations made with the instruments of the time, eight general observational diaries with various temporal resolutions, and seven diaries that 


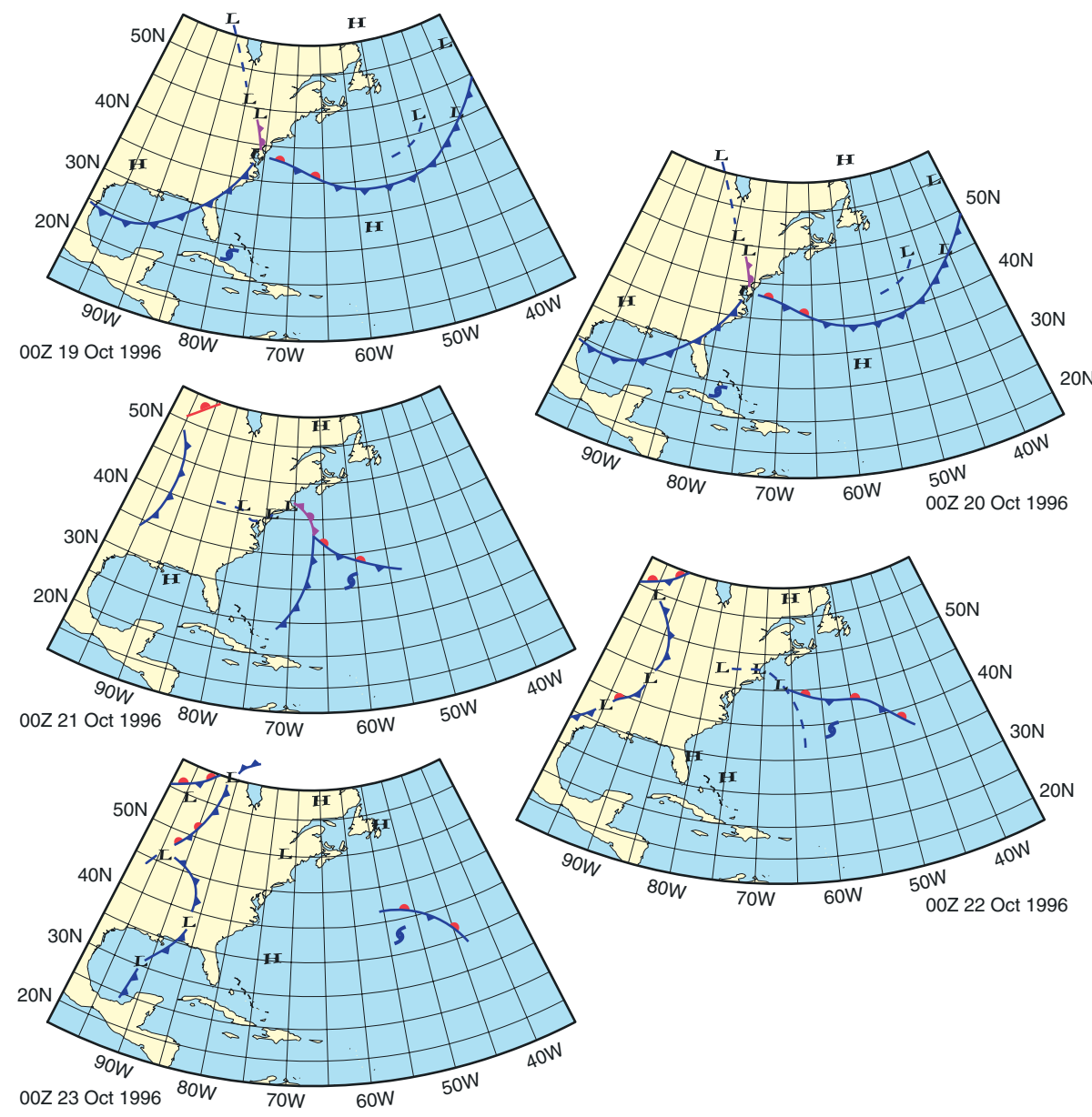

Figure 3. Synoptic maps from 00uTc 19-23 October, 1996.

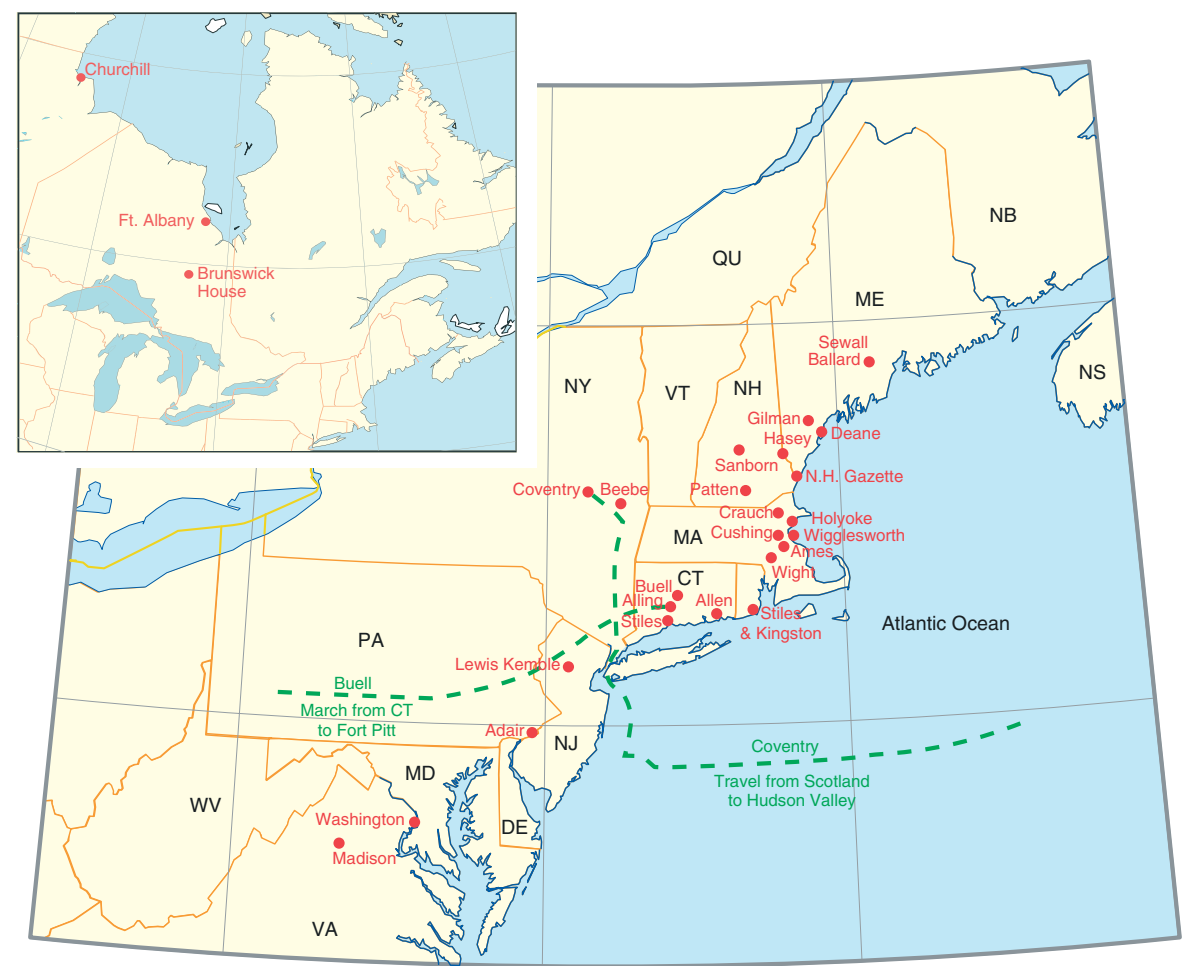

Figure 4. Network of observation sites used to reconstruct daily weather for 1785 .

contain anecdotal, or non-meteorological observational evidence (Figure 4). A number of individual comments were culled from eighteen other diaries as well, although with anecdotal and historical information was gathered from five newspapers from 1785 and early 1786 . Four ship's logs, thirteen ships' protests, and three Hudson's Bay Company factory records in Canada were also used. In this article we specifically focus on how ships' protests can potentially add important information allowing a more detailed reconstruction of severe storms that have impacted the eastern seaboard of the United States prior to systematic meteorological observations.

\section{October 1785 storm}

Reports of sustained heavy rain in October 1785 are geographically concentrated in the central New England area, but rain is mentioned in almost all of the sources throughout the north-eastern United States (McNally, 2004). Numerous comments speak to a 48-hour rain event, a 'hard, unceasing rain', and rapid flood or 'freshet'. The extent of the area affected by the October storm is also outlined by the widespread locations of the diarists. To the north, heavy rain and attendant damage are reported from Newbury, Vermont to Hallowell, Maine. Towards the south, record crests are reported on rivers in southern New Hampshire and northern Massachusetts. Disruptive rain is reported south to Virginia. Analysis of this spatial coverage indicates, however, that the bulk of the rain fell in southern Maine and New Hampshire.

Many records identify the specific damage sustained in the Presumpscot River Valley of southern Maine. When compared to the damage reported in the same area during the 18-22 October storm of 1996, the similarities become quite remarkable. Navigation and evacuation by canoe is common to both storms. There are mentions of washed-out bridges on the Presumpscot River in both cases as well. The intensity of the localized flooding and damage may indicate the presence of tropically enhanced rainfall, similar to the 1996 event. Indeed, there are no other events of this scale alluded to in any other sources from 1785. Other heavy or extended rain events do not produce the number or character of the comments from any of the diarists or observers. There are no other cases of such excessive flooding.

The 1785 event shows a number of similarities to that of October 1996, coincidentally including nearly identical dates. A cold-core high-pressure area moved eastward from Hudson Bay, a ridge from which was noted 18-19 October 1785 (Figure 5). Upper-level flow began to form a trough as a warm front passed northward through New Haven on the evening of 19 October. 'Stormy' weather was noted in Dedham, Massachusetts that evening (Ames, 1785). By the morning of 20 October, the front appears to have moved into the southern portion of the northern New England a very irregular temporal resolution. Some of these additional diaries were recorded at specific locations, while others are from travels of immigrants and soldiers. Additional 
states, while additional developing wet weather was described in the mid-Atlantic states. Horse races were postponed at Alexandria, Virginia (Washington, 1785), and Madison (1785) noted a 'very rainy morning'

By the afternoon of 20 October, it was clearing in Virginia, and a steady southerly flow with rain was established from Philadelphia to Massachusetts. 'Rain late' was noted in Salem, Massachusetts (Holyoke, 1785). On the morning of 21 October, as high pressure moved to the Quebec/Ontario border, surface low pressure appears to have moved very close to Massachusetts Bay. As the low continued to move just offshore, there were observations of winds shifting to the north and north-west in a wide area
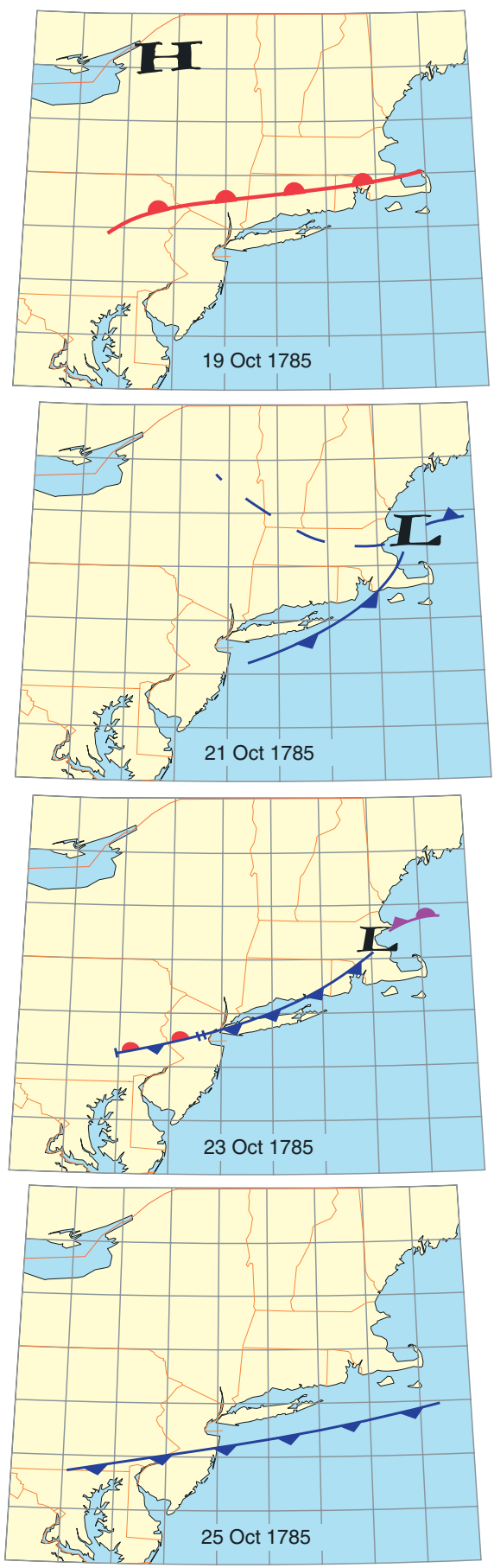
in Orange County, Virginia as well.

from south-central Maine to Pennsylvania. Madison (1785) reported some clearing, but noted 'atmosphere very thick'. During this entire time, heavy rains were reported in many locations, particularly in northern Massachusetts, southern New Hampshire, and southern Maine.

This supports the intensification of an upper-level, negatively tilted trough and occlusion. When compared with reports from southern New England, reports from southern Vermont, New Hampshire and Maine would indicate that those areas were north of a stalled warm or occluded front situated in Massachusetts. Forensic synoptic analysis of the previous few days also supports this assumption. This front may have deteriorated into a lingering trough, similar to the 1996
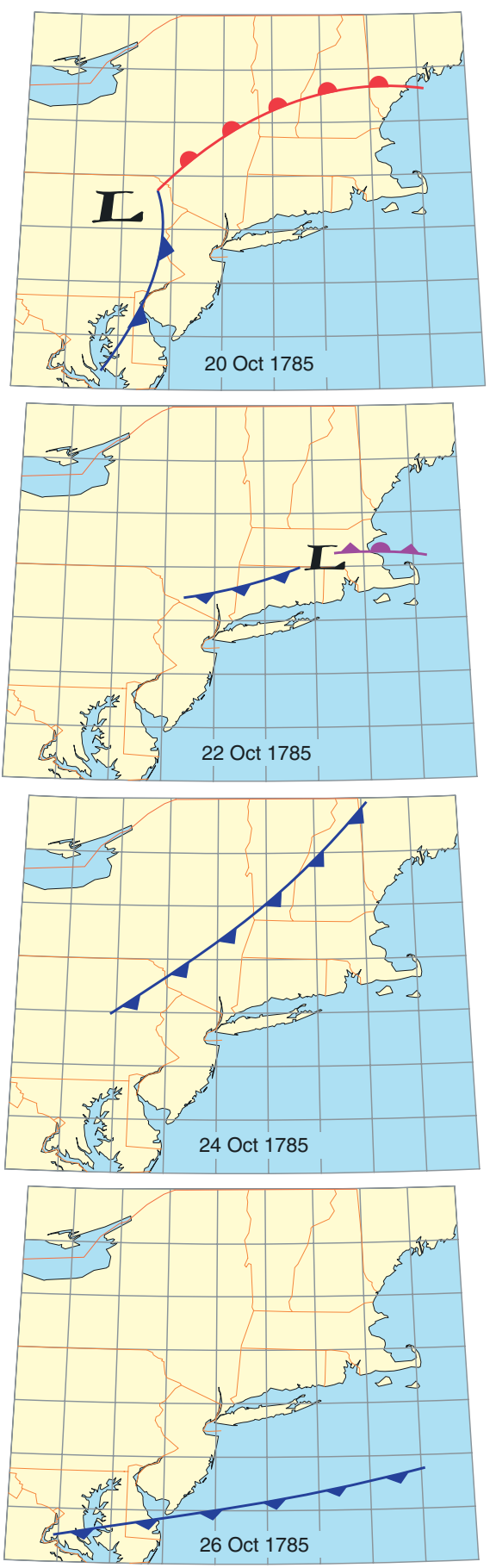

Figure 5. Reconstructed afternoon weather maps, 19-26 October, 1785. event, but the advective dynamics would have remained the same in either case.

The front would appear to be still south of Cape Ann, Massachusetts late on 21 October 1785. Reports of an onshore wind support this assumption. In fact, a Dutch ship was driven onto Plum Island on the night of 21 October, 1785 (Perley, 1891). This onshore flow supported a mechanism for tapping any moisture from the east. Additional evidence of rain off the ocean penetrating inland comes from numerous mentions of high water in the days following the storm. These reports are found in comments from Haverhill, Massachusetts, in the Merrimac River Valley, which would point to a heavy rain event upriver to the north (e.g. central and southern New Hampshire) a day or two earlier.

At this same time, 22 October 1785, two ships in the Atlantic Ocean, the brigantine Apollo and the schooner Nancy (Ships' protests, 1785) noted the rapid approach and passage of a strong 'gale', forcing the former onto the rocks at Bermuda, and damaging the latter sufficiently for her Captain to change course for Bermuda. Once in port, both Captains swore their protests, in which observations of the winds were consistent with the passage of a tropical storm or hurricane. The rapid passage of the 'gale' from late on the 22 nd to the $23 \mathrm{rd}$ was also consistent with the course of a hurricane that would have been captured by the long wave trough at or near the east coast of North America. In this type of capture and redirection of a tropical system, rapid northward acceleration would be expected. Therefore, bands of precipitation in the northern quadrants of the tropical system could have reached and been captured by the offshore warm front and driven into New England along the occlusion from late on the 21st into the 22nd, providing a source for the additional moisture outlined above (Figure 5).

By 22 October, the original primary surface low appears to have retrogressed back onshore in eastern Massachusetts, continuing the rainfall, and implying capture by a cut-off low at $500 \mathrm{HPa}(\mathrm{mb})$. Should that be the case, then very cold air would have begun to advect behind the system as it eventually drifted eastward and offshore to the initial long-wave trough position. In fact, by 23 October, a 'cool, stiff wind' from the west was reported in Connecticut, and rain ended in many locations. A secondary cold front on the 24th was located from New Hampshire to New York State. A 'great frost' was noted in Shrewsbury, Massachusetts by the 26th. The trailing front from the retreating storm was pushed south of Virginia and did not return. Cold Canadian air then advected in to the region.

\section{Comparison}

Both the 1785 system and the 1996 system developed an occlusion that connected the 
dying primary low with one on the triple point offshore. The 1785 case seems to have the primary low just offshore, while the 1996 system kept a surface low inland. Therefore, the positions of the now negatively tilted $500 \mathrm{HPa}(\mathrm{mb})$ troughs may be slightly different. However, the continued advection of moisture from offshore and sustained heavy rain necessitates the identification of an additional moisture source for the 1785 event, which may, in fact, have been a tropical system passing offshore. The precipitation from this system advected westward along the north side of the occlusion and/ or remnant trough into extreme southern Maine, New Hampshire, and in north-eastern Massachusetts. It was apparently centered on the Presumpscot River Valley in Maine. The pressure at Cambridge continued to fall, indicating continued intensification of the nearby primary low, or the passage of a tropical system nearby, thus enhancing the flow along the occlusion from offshore.

Surface analysis of the 1996 event (Cannon, 2000) indicates that Hurricane Lili ran northward in the Atlantic Ocean outside (east) of Bermuda, yet precipitation still reached New England. The reports from the Apollo and the Nancy indicate that the hurricane or tropical system of 1785 ran northward in the Atlantic inside (west) of Bermuda. This places the storm (and long-wave trough position) even closer to the North American continent, offering further evidence that tropical moisture was closer and tapped more efficiently in the 1785 event.

Although the passage of a tropical system so late in the season in 1785 might be initially discounted, thus assessing the 1785 system as a local disturbance, there is ample evidence of an active tropical storm season throughout the Caribbean in that year (Rappaport and Fernandez-Partagas, 1995). Indeed, numerous reports from newspapers of the time referred to hurricanes, one of which rivaled that of 1772 at Christianstaed, St Croix (Fowle's New Hampshire Gazette and General Advertiser, 1785). Newspaper reports from Jamaica reported severe damage from hurricanes that year. Lives were lost in the Cayman Islands (Williams, 1992). Storms were noted both at the end of August and in September, 1785. In fact, Hurricane Noel in late October 2007 followed a very similar track, though the storm was not involved with a synoptic system until it reached the Canadian Maritime Provinces.

\section{Conclusions}

There appear to be many similarities between the 18-22 October storm and flood of 1996, and that of on 18-22 October 1785, 211 years earlier. Forensic synoptic analysis shows that significant comparisons can be made of surface synoptic situation, and implied for the upper levels of the atmosphere. Comments and reports from both contemporary diarists and modern journalists are both similar and specific for each event in both spatial and temporal ranges. The similarity is further outlined by specific reports and results from the Presumpscot River Valley of southern Maine and surrounding areas for each event. As excessive rainfall was exacerbated by the advection of offshore tropical moisture in 1996 into the same river valley, a similar situation appears to have occurred in 1785 .

Assumptions have been made by various federal and state agencies regarding the expected recurrence of the 1996 storm, estimated to be in excess of a 400-500 year event (Hodgkins and Stewart, 1997; Keim, 1998). A reconstruction of the weather of 1785 and the similarity in the anecdotal comments surrounding both storms suggests that they can be directly compared. In both cases, a mature storm reaches occlusion nearby and flooding is exacerbated by the inclusion of moisture from an additional source. Hurricane Lili is the source in 1996, and, with the use of ships' protests from Bermuda, it appears that a tropical storm or hurricane is involved in our 1785 example as well. The two systems are 211 years apart, and this result is found with only the year 1785 having been investigated. Although 211 years does not provide the basis for statistical analysis, flood insurance and reinsurance rates, which may have been calculated on the 400-500-year basis of recurrence, eventually may need to be recalculated. The fact that the late-eighteenth-century research used herein only covers one year leads to a further conclusion that with reconstruction of additional years, the recurrence interval might, in fact, be even more frequent. We suggest that this method of reconstruction might serve well as a means to that end.

The value of further research into the ships' protests still available is evident, in the light of the potential contributions to both the insurance industry and the climatological research community. As paleotempestology becomes a more refined methodology, the identification of storms at sea, using forensic synoptic analysis as both a discovery and validation method becomes much more important. The use of the ships' protests can assist in this research and present an additional source of data for both identification of individual storms and expansion of the current hurricane database.

\section{Acknowledgements}

The authors wish to thank Dennis Wheeler as editor of this special issue of Weather. We are also grateful for the constructive comments and suggestions provided to us by two anonymous reviewers.

\section{References}

Ames N. 1785. Nathaniel Ames Diaries

1758-1822. Dedham Historical Society, Dedham, Massachusetts.
Cannon J. 1992. Structure and evolution of a flood producing storm - Southwest Maine, 11-12 May, 1989. Postprints, Third National Heavy Precipitation Workshop, Pittsburgh, PA, NOAA Technical Memo. NWS ER-87. Department of Commerce.

Cannon JW. 2000. A hydrometeorological assessment of the October 1996 record rainstorm in Maine. Eastern Region Technical Attachment No. 00-0.

Fowle's New Hampshire Gazette and General Advertiser. 1785. Atheneum Library, Portsmouth, New Hampshire.

Hodgkins G, Stewart G. 1997. Flood of October, 1996 in Southern Maine. US Department of the Interior, US Geological Survey, Water-Resources Investigations Report 97-4189.

Holyoke EA. 1785. Edward A. Holyoke Meteorological Journals, Salem, Massachusetts, 1754-1829. Harvard University Libraries, Cambridge,

Massachusetts.

Keim BD. 1998. Record precipitation totals from the coastal New England rainstorm of 20-21 October 1996. BAMS 79:1061-1067.

Madison J. 1785. Meteorological Journal Ms.; 1784-1793. American Philosophical Society, Philadelphia, Pennsylvania.

Malargus GM, Waldstreicher JS, Kocin PJ, Gigi AF, Marine RA. 1995. Winter weather forecasting through the eastern United States. Part I: an overview. Weather Forecasting 10: 5-20.

McNally LK III. 1994. Application of forensic synoptic analysis techniques for extraction and reconstruction of meteorological information from a non-homogeneous qualitative data set. MS Thesis, University of Maine, Orono, $90 \mathrm{pp}$

McNally LK III. 2004. The weather of 1785 : an interdisciplinary approach to meteorolological reconstructions using forensic synoptic analysis. PhD Thesis, University of Maine, Orono, $132 \mathrm{pp}$.

Perley S. 1891. Historic storms of New England. The Salem Press and Publishing Company, XXXIV:117-120.

Rappaport EN, Fernandez-Partagas J. 1995. The deadliest Atlantic tropical cyclones, 1492-present (updated by Beven J, 1997). National Hurricane Center: Coral Gables, Florida, http://www.nhc.noaa.gov/ pastdeadlytx1.html Accessed January 2004.

Sardinha A. 1998. Local climatological database of top precipitation events in Maine. NWS, Gray, Maine,

Washington G. 1785. The diaries of George Washington, Vol. IV, 1784-June 1786. Jackson D, Twohig D (eds). Charlottesville, University Press of Virginia, 1978.

Williams N. 1992. A history of the Cayman Islands. The Government of the Cayman Islands, Grand Cayman, 94 pp.

Correspondence to: Louis K. McNally, III Department of Applied Aviation Sciences, Embry-Riddle Aeronautical University, 600 S. Clyde Morris Blvd,

Daytona Beach, FL 32114-3900, USA

Email: lou.mcnally@erau.edu

c) Royal Meteorological Society, 2008

DOI: 10.1002/wea.272 